\title{
POTASSIUM-ARGON AGES ON A MESOZOIC THOLEIITIC DIKE SWARM IN RIO GRANDE DO NORTE, BRAZIL
}

\author{
PETER HORN*, DIETER MÜLLER-SOHNIUS* and AXEL SCHULT**
}

\begin{abstract}
Potassium-argon ages are reported for samples from four localities shich represent three laterally separated Mesozoic tholeiitic dikes in Precambrian of Rio Grande do Norte, Brazil. The ages for the dikes are between $167 \mathrm{Ma}$ and $130 \mathrm{Ma}$. It is shown that most of the ages determined are minimum ages due to argon losses. The methodological approach to identify argon losses is described. Ecess argon cannot be of significant influence on the ages found.
\end{abstract}

Resumo IDADES POTÁSSIO-ARGÔNIO DE UM ENXAME DE DIQUES TOLEfTICOS MESOZÓICOS NO RIO GRANDE DO NORTE, BRASIL. Foram determinadas idades K/Ar de quatro amostras coletadas de uma série de diques subparalelos localizados no Rio Grande do Norte. Os diques, constiturdos por rochas tolefticas, foram intrudidos no embasamento pre-cambriano. As idades obtudas se situam no intervalo de 167 a $130 \mathrm{Ma}$. A maioria dos resultados deve ser considerada como idade mínima, devido a perda de argônio. O método de identificaçăo de perda de argônio é descrito. A influência do excesso de argônio $e$ insignificante para as idades obtidas.

INTRODUCTION The east-west striking tholeiitic dike swarm in Rio Grande do Norte extends over a distance of about $200 \mathrm{~km}$ (Fig. 1) and cuts Precambrian basement (Sial 1976). Previous age determinations by the K/Ar method on seven samples (Cordani 1970, apud Sial 1976, Sial et al. 1981) and on five samples (apatites) by the fission track method (apud Sial 1976) yielded ages between $124 \mathrm{Ma}$ and $144 \mathrm{Ma}$, with a mean age of $131.5 \mathrm{Ma}$ (Early Cretaceous).

Recently, palaeomagnetic and rockmagnetic investigations on these rocks have been carried out (Guerreiro \& Schult 1983, Bücker et al. 1986). In this context, new potassium-argon age determinations were performed. The analytical details and results are presented in this article.

Analytical techniques, samples, dating approach and results Potassium analyses were performed in duplicate runs on aliquots by emission flame-photometry using cesium at a concentration of $1,000 \mathrm{ppm}$ as ionization buffer; potassium in the measuring solution was about $1 \mathrm{ppm}$. Sample weights of aliquots varied by a factor of $\sim 2$. Under these conditions, the analytical precision (relative standard deviation) is $\leqslant \pm 1 \%$. Accuracy is estimated to be $\leqslant \pm 1 \%$ (against interlaboratory standards).

Argon was analysed statically by direct calibration on a $180^{\circ}$ magnetic deflection MAT-230 mass-spectrometer. The all-metal extraction system (plus $50 \mathrm{mg}$ aluminium wrapping foil) has a blank of $\leqslant 8 \times 10^{-9} \mathrm{cc} \mathrm{STP} 40 \mathrm{Ar} / \mathrm{h}$ at $2,000^{\circ} \mathrm{C}$. Actual gas extraction required temperatures of up to $1,800^{\circ} \mathrm{C}$ to degas $\geqslant 99.5 \%$ of the radiogenic Ar from samples. The furnace was cleaned subsequent to each sample extraction by heating to $2,000^{\circ} \mathrm{C}$ for $20 \mathrm{~min}$. Sample weights for duplicate analyses of $\mathrm{Ar}$ were varied by a factor of 2 . The standard deviation for Ar concentrations is $\delta$ rel. $\pm 1.6 \%$. Total rel for the ages are given as $\delta_{\text {rel. }} \pm 3 \%$ (including calibration uncertainties, not including the uncertainty in the decay constant). Decay constants for $40_{K}$ are $\lambda \beta=4.962 x$ $10^{-10_{\mathrm{a}}^{-1}}$ and $\lambda_{\mathrm{e}}=0.581 \times 10^{-10_{\mathrm{a}}^{-1}} ; 40_{\mathrm{K}} / \mathrm{K}=1.167 \mathrm{x}$ $10^{-4}$.

The samples were prepared from $2.5 \times 2.5 \mathrm{~cm}$ drill cores as taken in the field for rock - and palaeomagnetic work (Bücker et al. 1986) by crushing, sieving and magnetic separation of plagioclases and clinoproxenes on a Frantz magnetic separator. Grain sizes of the samples were between 250 and $100 \mu \mathrm{m}$ for whole rocks and $150-100 \mu \mathrm{m}$ for minerals.

Thin sections of the samples revealed the presence of devitrified glasses with skeletons of opaques and small, but varying degrees of plagioclase alteration (saussuritization).Pyroxenes as phenocrysts and in the mesostasis are appearing fresh. Small biotites (present only in sample 47) are unaltered.

Diffusional argon-losses are to be expected from the devitrified glasses and altered plagioclases. Concurrently, glasses from deep and altered plagioclases. Concurrently, glasses from deep-seated sills and dikes are frequently the locii of excess-argon, especially when the contry rock is as old as Precambrian. Therefore, we applied acid-eteching by a $6 \%$ HF-solution (5 minutes, room-temperature) to the whole-rocks and plagioclase from one sample in order to remove glass and devitrification products thereof, respectively, and altered portions of the plagioclases, known to dissolve preferably upon etching. Systematic investigations on the etching-technique (Horn \& Müller-Sohnius to be published) revealed that no artifacts such as differential removal of argon and potassium are intruduced. This approach can be regarded as an analogy to the stepwise-heating- ${ }^{40} \mathrm{Ar} /{ }^{39} \mathrm{Ar}$-dating technique qualitatively (chemical plateau-method). It must be noted, that after etching whole-rock samples tend to carry high atmospheric argon concentrations relative to unetched samples. Therefore, ultrasonic treatment was applied to the etched samples to

\footnotetext{
* Mineralogisch-Petrographisches Institut der Universität Munchen, Theresienstrasse 41, 8000 München 2, República Federal da Alemanha

** Institut für allgemeine und Angewandte Geophysik der Universitat München, Theresienstrasse 41, 8000 München 2, República Federal da Alemanha
} 
remove newly formed fine grained fluorides which can be identified as major carriers for atmospheric argon.

Pure plagioclase concentrates were analyzed here in that this mineral can be considered as reliable Ar-chronometer for volcanics in most instances - if fresh. In our cases, it was anticipated that the plagioclases may have lost some radiogenic argon due to slight alterations. In turn, however, plagioclases may here also be in part contaminants from the Precambrian country-rocks and which could then have retained - inherited - radiogenic argon. To check for these two - conflicting - possibilities was a further rationale for including the plagioclase in this study. In minerals from intrusive dikes occassionally excess argon is observed, especially in minerals of low potassium contents such as pyroxenes. To learn about the possible magnitude of the effect of exces argon on the ages, we analyzed a pure clinopyroxene concentrate from sample 43.

The analytical results and calculated ages are presented in table 1 .

Discussion From the table it can be seen that in every case but for sample n- 46 the ages of the etched whole rock correspond to its relative clear apearance among the different plagioclases - is closest to the most likely age. It is this the very same sample, where etched and unetched whole-rocks are concordant in age.

Compared to the ages for the etched whole-rocks the samples are higher than the corresponding untreated whole-rocks. Also, the plagioclases' ages each are lower than the ages of the etched whole-rocks. We, therefore, prefer the ages of the latter as being relatively closest to the age of emplacement of the basaltic dikes; the plagioclase concentrate (n. 46) with highest potassium content - which might plagioclase samples (but one, see above) are significantly lower in age and most likely reveal argon-losses. Therefore, we are forced to regard also the etched whole-rocks to be lowered due to argon-losses in that etching does not necessarily remove alteration products quantitatively. Hence, for samples 43,44 , and 47 the ages of 161,145 , and $167 \mathrm{Ma}$, respectively are minimum ages: samples 43 and 47 apparently belong to the very same dike system II (Fig. 1): as their calculated ages are concordant at $164 \pm 5 \mathrm{Ma}$ within the given analytical uncertainties, we regard it as the respective minimal age for dike II, which corresponds to Middle Jurassic.

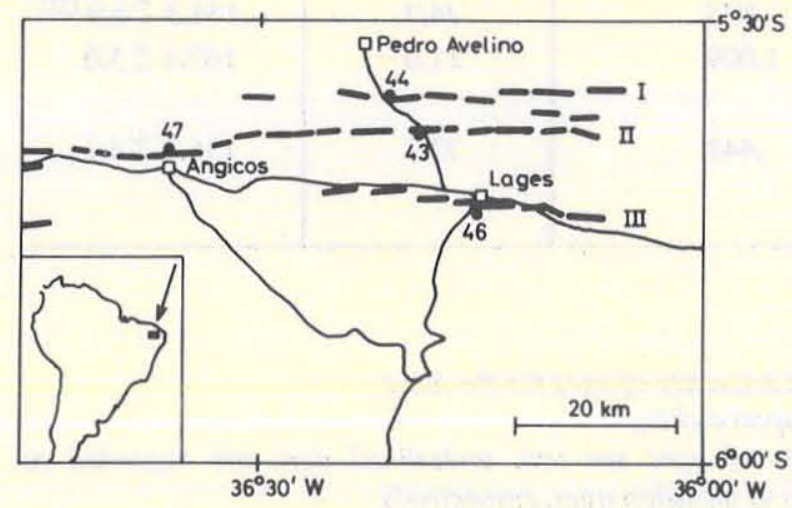

Figure 1 - Sketch map showing dikes (I, II, and III) and sample locations in Rio Grande do Norte
The only sample for which the ages are concordant for all three sample varieties is sample 46 which has an age of 130 $\pm 4 \mathrm{Ma}$ and which therefore can be regarded as the age of emplacement of the respective dike or sequence of dikes III (Early Cretaceous).

Cordani (1970) determined a whole-rock age for a sample from near Angicos which is $134.3 \pm 3.9 \mathrm{Ma}$ (Tab. 1). Our etched whole-rock sample from the same locality (no. 47), however, has a minimum age of $164 \pm 5 \mathrm{Ma}$ (see above). The etched plagioclase from there reveals 136,8 $\pm 4 \mathrm{Ma}$ and evidently has lost argon at some time. Most likely, the age given by Cordani (op. cit) is also lowered by argon-loss.

Sial et al. (1981) concluded from whole rock K-Ar and fission-track ages on apatites (Sial 1974) that the dikes investigated should be not younger than $125 \mathrm{Ma}$ (actually from $125 \mathrm{Ma}$ to $129 \mathrm{Ma}$ ) and that their $\mathrm{K}-\mathrm{Ar}$ ages up to 144 Ma might be due to extraneous argon (either inherited or excess argon). In view of our high ages and Sial et al. 's (op. cit.) suggestions, we have to consider the possibility of extraneous argon beeing responsible for the high ages found here. Therefore, from sample 43, which reveals the largest discrepancy of ages for plagioclase and etched whole rocks (Tab. 1), we analyzed a clinopyroxene concentrate. Here, due to low potassium concentrations, extraneous argon should show up most readily. In effect, a relatively high age of 179 Ma for the pyroxene is found (Tab. 1), corresponding to an excess of argon of $6.8 \times 10^{-8} \mathrm{cc} \mathrm{STP/g}$ if we take - for the sake of argument - Sial et al.'s age of $125 \mathrm{Ma}$ as reference. This is less than $1 \%$ of the argon concentrations measured for all whole rocks (etched and unetched) and has therefore - if present also in the whole rocks in about this proportion no influence on their ages.

For devitrified glass in whole rock sample 43 we can calculate an age from data given in table 1 as $159 \mathrm{Ma}$, hence very close to the age of the etched whole rock (161 Ma). As almost with certainty we can assume partial argon losses for devitrified glasses in general, this implies also lowered argon contents for the etched whole rock, in agreement with our reasoning discribed above.

Furthermore, potassium and argon concentrations calculated for material dissolved by the etching process (Tab. 1), were high and reveal argon losses as its age would be only $127 \mathrm{Ma}$. In any case argon-losses supersede potential excess-argon - if there was any.

In the cases of unetched/etched whole rocks (ns. 44 and 46), the dissolved material had lost argon ( $n \div$. 44) or is concordant in age with the intrusion age for the dike (n‥46) indicating that we are on the age-plateau of the chemical plateau-method in the latter case.

With these data sets at hand, we interpret the ages obtained: due to argon losses at ambient temperatures over the times all but one of the ages determined are low relative to the intrusion ages; those found for etched whole rocks are closest to intrusion ages - nevertheless are minimum ages (145 Ma for sample 44 and $167 \mathrm{Ma}$ for sample 47). According to the methodological chemical plateau approach, sample 46 has an intrusion age of $130 \mathrm{Ma}$.

For sample 43, the minimal age is $161 \mathrm{Ma}$ and the maximal age $179 \mathrm{Ma}$ - if the pyroxene concentrate actually contains excess argon (for which effect no definite proof can be given because adequate reference phases are lacking!).

Some of the low ages (125 Ma - $144 \mathrm{Ma}$ ) reported in the literature for the dikes we also consider as being affected by argon losses and by fission track-annealing in the apatites. 
Table 1 - Measured and calculated potassium and argon concentrations for dike material and ages thereof

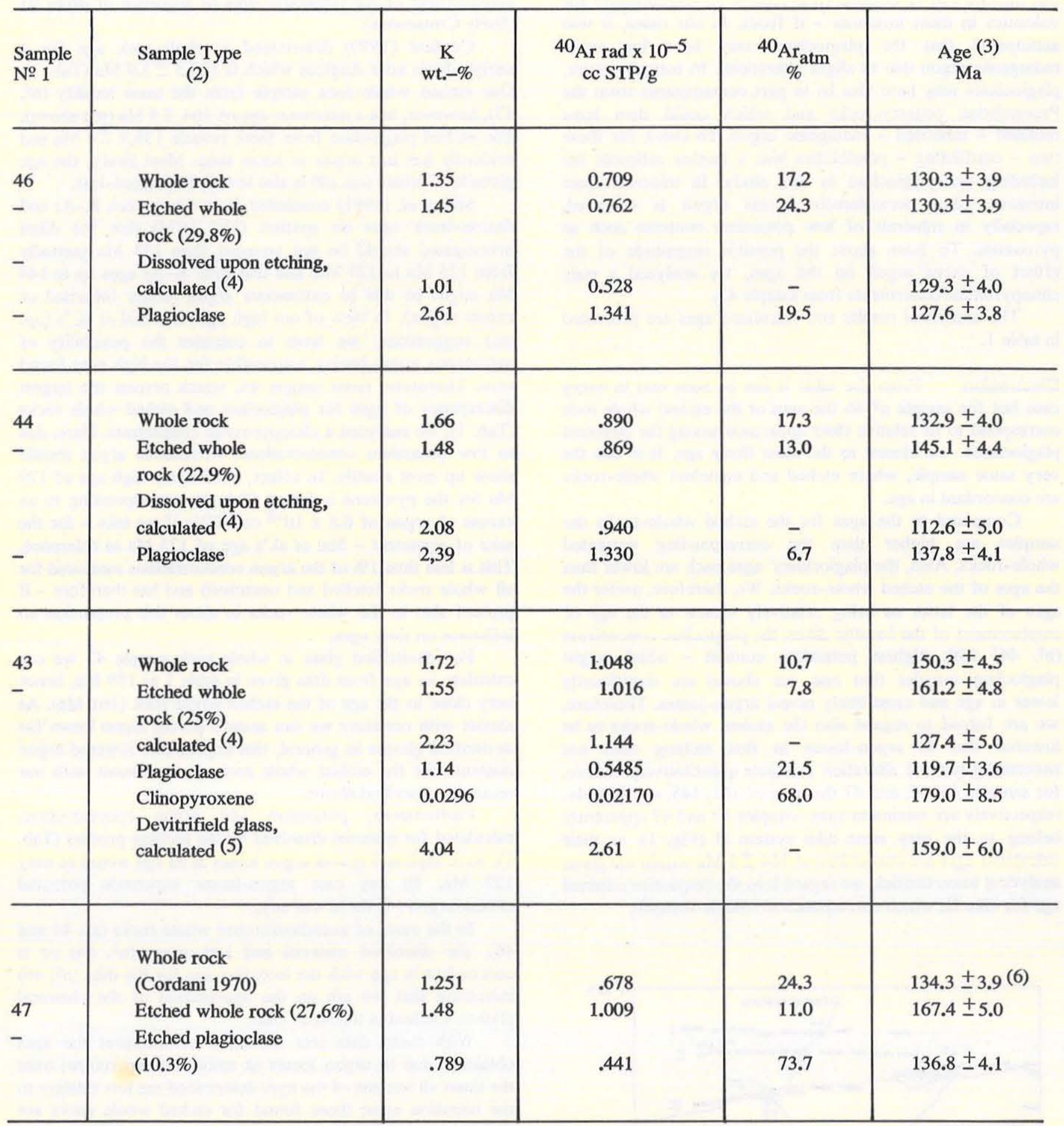

(1) Numbers refer to sampling localities in figure 1 and are arranged in sequence of ages for the dikes

(2) See text for explanation; percentages in brackets are weight-losses upon etching

(3) For constants used, analytical uncertainties and interpretations of ages see text; underlined ages are regarded as representing intrusion ages ( $\left.N^{\circ}-46\right)$ and minimum ages which are closest to intrusion ages, respectively

(4) Calculated form mass-balance and analytical data for etched and unetched whole rock

(5) Calculated from volume-ratio plagioclase:clinopyroxene:devitrifield glass $=1 / 3: 1 / 3: 1 / 3$ after modal composition and analytical data for the whole rock (unetched), plagioclase and clinopyroxene

(6) Re-calculated with constants used in this paper form data given by Cordani (1970) 
Without quantisizing the argument we note that total track annealing in apatite takes, place at temperatures and times (arond $110^{\circ} \mathrm{C}$ and $1 \mathrm{Ma}$ ), while argon is well retained by most minerals over much longer times. The fact that the ages at the low end of the age sequence determined for the Mesozoic dikes in the region (125 Ma-129 Ma) are apatite fission track ages is further support of our view that the temperature dependent argon retention model is applicable: assumptions about excess argon are more speculative.

Independent arguments for higher ages than $125 \mathrm{Ma}$ among the dikes are that the palaeomagnetic pole position for the dike swarm is closer to the Jurassic poles of South America than to the Early Cretaceous poles (Bücker et al. 1986). However, as it appears dike II is appreciable older than dikes I and III. Hence, instead of one mean pole position two pole positions can be calculated for the sites collected from dike I, III, and dike II, respectively (Bücker et al. 1986, Table 1). This yields different pole positions at 85.1ㅇN $329{ }^{\circ} \mathrm{E}$ ( $\mathrm{A}_{95}$ $=4.0^{\circ}$ with five sites) (dikes I and III) and at $67.7^{\circ} \mathrm{N} .106^{\circ} \mathrm{E}$ ( $A_{95}=10.3^{\circ}$ with five sites) (dike III). The pole for dikes I and III is near to Early Cretaceous poles from South America and the pole for dike II is not far from a Jurassic pole from the Amazon basin (Bücker op. cit., Fig. 3). As there are five sites only for each pole of the dikes the significance is not large but nevertheless the palaeomagnetic results are consistent with the ages determined.

CONCLUSIONS The K-Ar ages for specimen from four localities from three laterally separated tholeiitic dikes range from $167 \mathrm{Ma}$ to $130 \mathrm{Ma}$.

Previous age determinations on whole-rocks from the region indicated an emplacement of the dike swarm between $145 \mathrm{Ma}$ and $125 \mathrm{Ma}$ ago. Our slightly higher ages on these rocks correspond to Middle/Late Jurassic and to Early Cretaceous. Palaeomagnetic results for the dike swarm are consistent with these ages.

Acknowledgments Financial support of one of us (A. Sch.) by Conselho Nacional do Desenvolvimento Científico e Tecnologico $(\mathrm{CNPq})$ and Deutsche Forschungsgemeinschaft is gratefully acknowledged. We thank Ms. Tumminaro for typing the manuscript.

\section{REFERÊNCIAS BIBLIOGRÁFICAS}

BÜCKER, C.; SCHULT, A.: BLOCH, W., GUERREIRO, S.D.C. 1986 Rockmagnetism and palaemognetism of an Early Cretaceous/Late Jurassic dike swarm in Rio Grande do Norte, Brazil. J. Geophy., 60:129-135.

CORDANI, U.G., 1970 Idade do vulcanismo no Oceano Atlântico Sul. Bol. Inst. Geoc. Astron., 1:9-75

GUERREIRO, S.D.C. \& SCHULT, A. 1983 Paleomagnetismo de um enxame de diques toleiíticos de idade mesocenozóica, localizados no Rio Grande do Norte, Rev. Bras. Geof., 1:89-96

SIAL, A. N. 1976 The post-Palaeozoic volcanismo of Northeast Brazil and its tectonic significance., An. Acad. bras. Ciênc., 48(supl.):299. 311
SIAL, A.N.; LONG, L.E.; PESSOA, D.A.R.; KAWASHITA, K. 1981 Potassium-argon ages and strontium isotope geochimistry of Mesozoic and Tertiary basaltic rocks, northeastern Brazil. An. Acad. bras. Ciênc., 53(1):115-112.

...Geбlogos exploracionistas do século XXI terão, eu me atrevo a dizer, os beneff́cios de muitas percepçoses novas baseadas em evidências atualisticas. 